\title{
Campylobacter curvus
}

National Cancer Institute

\section{Source}

National Cancer Institute. Campylobacter curvus. NCI Thesaurus. Code C86232.

A species of microaerophilic, Gram-negative, curved or spiral bacilli assigned to the phylum Proteobacteria. This species is motile using a single polar flagellum, non-spore forming, oxidase positive, catalase negative and produces both formate and acetate. C. curvus, formerly known as Wolinella curva, is a rare pathogen associated with cases of bloody and Brainerd's diarrhea. 